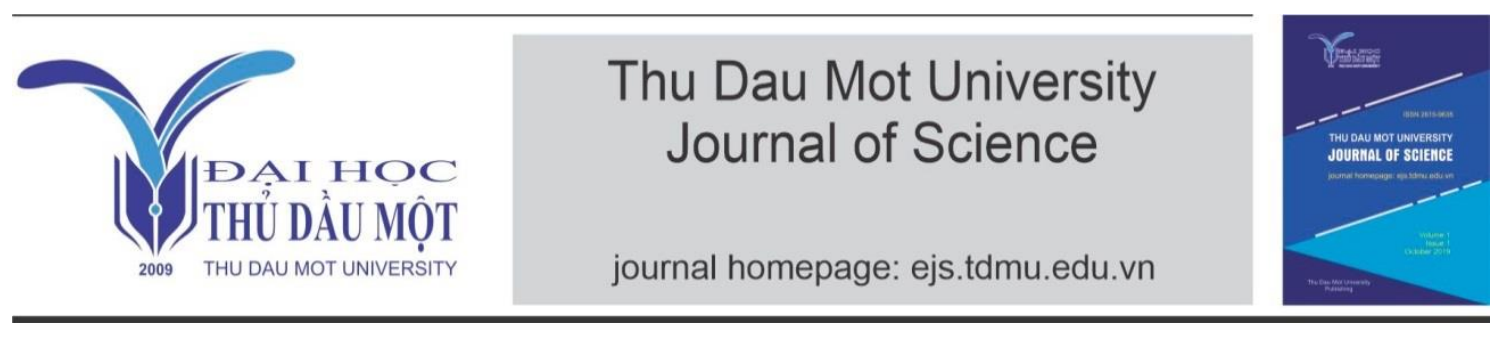

\title{
Industrialization and modernization process in the Southeast region (2010-2020) - some experiences
}

by Pham Ngoc Tram, Tran Minh Duc, Bui Duc Anh (Thu Dau Mot University).

Article Info: Received 10 April. 2021, Accepted 2 June 2021, Available online 15 June 2021

Corresponding author: trampn@tmdu.edu.vn

https://doi.org/10.37550/tdmu.EJS/2021.02.207

\begin{abstract}
The study reflects generally the process of industrialization and modernization in the Southeast provinces and cities of Vietnam (2010 - 2020) and the results achieved in that process.

From that practice, the article has summarized some experiences on industrialization and modernization in the Southeast region, contributing to bringing Vietnam to complete the goal of industrialization and modernization, basically become a modernity-oriented industrial nation.
\end{abstract}

Keywords: industrialization, modernization, modern industry, Southeast region, Vietnam

\section{Introduction}

The Southeast region has a very important position and role in the socio-economic development of the country. The Southeast region has been at the forefront in the cause of industrialization and modernization, especially in the development of high-tech industry, electronics industry, informatics is the cradle of start-up and pioneering activities which are innovative and creative; research, application and implementation of science and technology; train highly qualified human resources, form science and technology centers, education and training centers of international stature. With that potential, the Southeast region is the driving force for the socio-economic development of the region and the whole country. 
In order to promote the general development of the whole country as well as create linkages and coordination in socio-economic development among economic regions, one of the key breakthrough factors is to accelerate industrialization - modernization in the Southeast region in order to accelerate economic restructuring, including sectoral structure, economic component structure and economic region structure. The promotion of the implementation of industrial and infrastructure development policies in the local plannings and in the industrial and infrastructure plannings has set the right direction in development, especially the development of many industrial parks in the Southeast region, enhancing Vietnam's position in the process of industrialization and modernization.

In the context that the fourth industrial revolution is having a strong impact on the industrialization and modernization process in our country, although accounting for a high proportion of the national economy, the Southeast region has not yet developed to the right level. From the reality of the Southeast region, it is necessary to have many solutions to comprehensively develop the economy - society, develop the economy society comprehensively, create motivation for development, and draw lessons from experience for the Southeast key economic region in particular and for Vietnam in general in the process of industrialization and modernization towards modernity.

\section{Literature review}

The research questions posed in this article are: (i) What core experiences did we get from the achievements of the Southeast key economic region in recent years associated with industrialization and modernization? Are those experiences relevant to Vietnam nowadays? (ii) It is necessary to discuss more deeply about the lessons learned for Vietnam in implementing the country's economic development in association with technological innovation, start-ups, capital accumulation and talent development, which are very successful in Japan, Korea, Israel, etc... in the process of becoming an industrial country.

The work of Scott and Storper (1992) brings together studies to build a foundation from which to deal with a new economic order. The authors argue that the world has witnessed a shift in socio-economic relations, patterns and processes of regional industrialization and development. The social regulation of the economic order, the flexible organization of production, and the formation of the industrial zone have brought the periods, places, and paths of industrialization into the heart of economic debates.

Xuan (2011) focused on researching general theoretical issues about industrialization and some industrialization models in the world and in Vietnam. The author analyzed the 
model of industrialization in Vietnam from 1960 to 2010, implications for policy in the coming period. Szirmai et al. (2013) studied the model of industrialization in the world over the past two centuries, summarizing a number of countries' experiences. Phuong (2019) focused on researching and clarifying the general characteristics of Vietnam's industrialization and modernization process in the period 1996 - 2018, assessing the impact of these characteristics on the content as well as on the process, speed and results of the industrialization and modernization of Vietnam. Chang and Andreoni (2020) researched and developed a new theory of industrial policy, incorporated some issues that have been neglected so far and taking into account recent changes in economic reality.

Ohno (2006) pointed out that Japan is a latecomer but has succeeded in catching up with the West to become one of the world's leading industrial countries. The author believes that the experiences that Japan has gone through will be very useful for Vietnam. Cuong (2013) from practical research on the path of "agricultural modernization with Chinese characteristics", drew a number of lessons from modernizing and building a prosperous and progressive rural area. Huong (2015) studied the miraculous development of Korea and Singapore. The author explains the reasons for using human resources and financial resources here; specifically study the process of attracting - using financial resources as well as the strategy of training and using human resources of Singapore and Korea in the period 1961-1979.

Research by Sen and Tien (2013) analyzed the leading role of the South, including the Southeast region, along with Vietnam, carried out the renovation work, moved towards industrialization - modernization, held an important position and role in the international integration process of Vietnam. Long (2016) presented an overview of social change and the foundations of the social change process in Ho Chi Minh City, Dong Nai and Binh Duong in the first twenty years of renovation (1986-2006).

Huy (2019) focused on analyzing and clarifying the theoretical and practical basis of the factors affecting the attraction of foreign direct investment inflows into the economic zone of a country; on that basis, analyzed and evaluated the factors affecting the attraction of FDI inflows into the Southeast economic region.

\section{Methodology}

The article is made on the basis of Marxist's worldview and methodology, the views of scientists and organizations in the world and Vietnam on industrialization and modernization

The systems approach is used to analyze the role of science and technology in the 
growth model. The advantages and achievements for promoting the role of science and technology in the growth model in Vietnam are evaluated and described with the help of objective data from statistical sources and officially announced. The systems approach is used to analyze industrialization and modernization for socio-economic development in the Southeast region. The advantages and results achieved in the process of industrialization and modernization in the Southeast region, Vietnam are evaluated and described with the help of objective data from statistical and published sources.vAt the same time, the article also uses a combination of specific research methods such as historical, logical, comparative, analytical, synthesis, inductive and deductive, data synthesis... research and presentation of articles.

\section{Results and discussion}

\section{Result}

The Southeast region, including Ho Chi Minh City and provinces like Ba Ria - Vung Tau, Dong Nai, Binh Duong, Binh Phuoc and Tay Ninh, is a dynamic economic region with high and sustainable economic growth, known as the locomotive of economic development of the country. The economic development level of the Southeast region is generally higher than that of the whole country in most industries and fields (high-tech industry, tourism services, telecommunications, finance, banking; research, application and deployment, human resource training). The Southeast is the largest industrial center of the country. A dense network of industrial parks, concentrated in the quadrilateral Ho Chi Minh City, Binh Duong, Dong Nai and Ba Ria - Vung Tau. Up to now, the Southeast region accounts for about $40 \%$ of GDP, contributing nearly $60 \%$ of national budget revenue, GDP per capita is nearly 2.5 times higher than the national average; has the highest urbanization rate in the country; the region's economic growth rate is always about 1.4 - 1.6 times higher than the national average growth rate.

Besides, the Southeast economic region with the nucleus is Ho Chi Minh City - where training institutions, scientific research, medical centers are concentrated; where there is abundant and skilled human resources, is the hub of services and trade of regional and international stature, so it is an attractive investment environment. In the region, a satellite urban network has been formed, in an open and airy space, linked together through the axis and belt routes under construction. The Southeast region is also the largest international integration center in the country with Cai Mep - Thi Vai international transit seaport, Tan Son Nhat international airport and Long Thanh international airport (it is going to be built). Southeast region is a dynamic economic one, leading in attracting foreign direct investment (FDI). Up to now, the region accounts for about $60 \%$ of projects and nearly $50 \%$ of the country's FDI, and the 
region's export turnover accounts for nearly $60 \%$ of the country's total export turnover.

According to the target, the Southeast region strived for the average economic growth rate (GDP) in the period 2011-2020 to reach 9.5\%-10\%/year. By 2015, GDP per capita was equivalent to 4,600 USD and in 2020 it reached 6,400 USD. The proportion of industry, construction and services accounts for $97-98 \%$ of the region's total GDP in 2020 , of which services accounted for over $44 \%$, higher than the national average. The rate of technological innovation reached an average of 20-25\%/year; raised the rate of trained laborers to over $90 \%$ by 2020 . We formed centers of high-quality production and social services, reaching international and Southeast Asian standards.

\section{Limitations}

Development is still spontaneous, unsustainable, regional planning is not enough to cover comprehensive and balanced development; connection; coordination between provinces and cities in the region is not close, and the overall effectiveness is still limited. In recent years, a number of restraining factors have been revealed, so potential and advantages have not been fully promoted: low internal accumulation, low added value in goods; industry is still basically processing and preliminary processing; industrial parks and export processing zones are not properly distributed; productivity, quality and competitiveness of products are still low; the proportion of services decreased, not keeping up with competitive requirements in international economic integration; environmental pollution increases; Mechanical migration and some social problems are still complicated. The relationship between economic growth and socioeconomic infrastructure development and environmental protection has not been well resolved. The socio-economic development of the region is not homological, the development level in rural areas, especially the three provinces of Binh Phuoc, Tay Ninh and Long An is still low.

It can be seen that the above limitations are due to the potential and advantages of the region that have not been fully and consistently understood by central ministries, branches and localities, thereby not having a sufficient system of mechanisms and policies to determine synchronous direction, creating conditions for the most dynamic economic region of the country to develop to the maximum; besides, the leadership capacity of the party committees and administration of the local government has not yet met the requirements of the region's development tasks; Thirdly, the direction and coordination between central ministries and branches and provinces and cities is not tight in formulating and managing the implementation of the overall master plan of the whole region, of each province, city and other provinces.

From the actual situation of the process of industrialization and modernization of the Southeast provinces - Having drawn lessons from the process of implementing 


\section{industrialization and modernization of Vietnam in the period 2010-2020}

First, promoting the process of industrialization and modernization of the country is associated with creating strong socio-economic, cultural and technological changes in the direction of progress.

The process of industrialization and modernization in the Southeast region has strongly shifted from manual production to mechanization, formed a series of new industries, and witnessed the remarkable development of the steel, chemical, and electricity industries, oil. The industrialization process is associated with the OS through a combination of smart software (desktop computers, phones), the internet and renewable energy sources, promoting the explosive digital technology... have magical results, such as from manual storage to digital data; introduced automatic teller machines (ATMs), industrial robots; CGI in film and television, electronic music, bulletin board systems, video games.

The process of industrialization and modernization has changed the trend of fuel use and enhanced the role of renewable energy such as solar energy, wind, hydroelectricity, heat, waves and tides...; development of the media and retail industry allows SMEs to thrive, global companies will coordinate and manage trade throughout the value chain. On the basis of digital technology and integrating all smart technologies, Vietnam needs to promote optimization of production processes and methods, form and develop 3D printing, biotechnology, new material technology, automation technology and robotics (artificial intelligence) in the coming time.

Second, industrialization - modernization in Vietnam continues to accelerate the transition from an industrial economy to a knowledge economy.

In the Southeast region, Vietnam, the process of industrialization and modernization has been accelerated, the industrial economy has favorable conditions for technical development, the production force has developed rapidly at a high level.

In the process of industrialization and modernization, emphasis is placed on the role of science and technology in industrial development, so production relations are more advanced, and technology is the basic factor of development. The State should focus on the application of scientific - technological advances, technological innovation to create driving force for socio-economic development. That process inevitably leads to the formation and development of new industries representing scientific and technological progress. At the same time, under the influence of technological innovation, the industry structure will be more diversified, richer and more complex; industries with high science - technology content will develop faster than traditional industries that consume a lot of raw materials and energy. Advances in science and technology and technological innovation will allow to improve quality product quality, create many new 
products, diversify products, increase output, increase labor productivity, rationally use, save raw materials.

As a result, the industrial economy will increase competitiveness, expand markets, promote rapid growth and improve production and business efficiency. Scientific and technological progress and technological innovation will solve the tasks of protecting the environment, improving living and working conditions, reducing heavy and hazardous labor, transforming the labor structure towards: to increase the proportion of skilled and skilled workers, to reduce unskilled and unskilled labor. At the same time, scientific and technological progress promotes the development of the social division of labor at each level of technology with appropriate forms and levels of division of labor. At the same time, scientific and technological progress promotes the development of the social division of labor at each level of technology with appropriate forms and levels of division of labor. The rational social division of labor is a favorable environment to promote scientific and technological progress. The redistribution of labor is the direct agent of the industrial formation and the internal division of the industry into different modules. Therefore, the higher the level of scientific and technological progress, the deeper the social division of labor, the stronger the industrial division, and the more complicated the industrial structure.

The process of industrialization and modernization in the Southeast region, Vietnam together with the transition from an industrial economy to a market economy has created a transformation of the economic structure in the direction of service and high technology.

It can be said that the process of industrialization - modernization has accelerated the transition from an industrial economy to a knowledge economy in the early years of the 21 st century. In the process of industrialization, modernization, science and technology. Technology in Vietnam plays an important role in strongly developing the production force, renewing the growth model, improving the people's quality of life and consolidating national defense and security. However, the reality of science and technology development and innovation in Vietnam still has many limitations and shortcomings, which have not really become the most important driving force in the development process, such as: science and technology of social production is still low; the application of science - engineering - technology to agricultural production has not been carried out synchronously; the rate of enterprises having R\&D in industries is still very low; investment in science and technology activities is low, the structure is not suitable, the efficiency is low... has been negatively affecting the renewal of the growth model in Vietnam today, which requires Vietnam. It is necessary to synchronously implement the above solutions to promote the role of science and technology in 
renovating the growth model in Vietnam, contributing to rapidly increasing productivity, quality, efficiency and competitiveness of the economy, rapid and sustainable development of the country; increase the contribution rate of factors of total productivity and growth.

Third, in the process of industrialization and modernization, Vietnam needs to focus on effective investment in developing high-quality human ressources.

One of the important lessons learned from industrialization and modernization in the Southeast region, Vietnam nowadays is investing in developing high-quality human resources. It is necessary to be very aware that in order to shorten the development gap, it is necessary to invest in developing high-quality human resources. This means that if you do not invest in developing high-quality human resources, you will face the risk of falling further behind.

It is an obvious fact that countries that possess a lot of knowledge, high-quality human resources and know how to make good use of opportunities will be able to break through to become the leading developed economies. In the process of industrialization and modernization of Vietnam, it is necessary to give more priority to science technology and education.

Fourth, the success of the path of industrialization and modernization in Vietnam is associated with innovative thinking and the level of international integration.

Promote international cooperation and integration, promote joint research cooperation to take advantage of the resources and knowledge of advanced countries, and step by step raise the domestic research capacity and level to be able to participate in partnership cooperation for equality and mutual benefit in the long term. Strongly support scientific exchanges, regional and international academic exchanges. Develop and improve the operational efficiency of the network of Vietnamese science and technology representatives abroad, especially in key areas. Attracting and exploiting the strengths of a team of talented Vietnamese scientists abroad.

In the coming period, the process of international economic and financial integration will continue to take place deeply and greatly affect the development of most countries. Globalization of trade, financial investment and currency will take place strongly. Along with that will be the internationalization of the financial - monetary system, leading to an increasing interdependence on a global scale. Along with the accelerating globalization process, competition among countries for capital, resources and technology will also be more intense. Scientific and technical progress continues to be a tool to promote international cooperation and orient the world's economic and financial development, and at the same time create favorable opportunities for latecomer countries to catch up and participate in the chain. global economy. 
The international political, economic and financial relations are increasingly important and mutually influencing each other, and globalization will also reduce the independence in the implementation of economic policy in general and financial countries in particular. The world economy is forecasted to have unpredictable changes. The gap between groups of developed countries and less developed economies tends to increase. The crisis response and resolution policy along with the recovery process of the world economy will bring some changes in the structure, as well as the method of macro management of many economies.

\section{Conclusion}

The Southeast region and the southern key economic region have great potential and advantages and are also regions with a very important position and role, as a driving force for the region's socio-economic development and the whole region. Along with the potentials and advantages, in the face of new requirements on socio-economic development, a number of limitations and challenges emerge in the region more and more clearly. To strive to continue to become a leading region in the cause of industrialization and modernization of the country and international economic integration, having the effect of attracting and supporting other regions. The Southeast region needs to review the master plan for socio-economic development of the region, in order to bring into full play the potential and advantages for rapid, effective, sustainable, civilized and modern development. It is necessary to have mechanisms and policies suitable to the level of market economic development and the requirements of international economic integration of the region in order to strongly encourage the mobilization of capital for development investment right from the internal resources of the region. Above all, it is necessary to invest in applying science and high technology to develop production and services; review and adjust mechanisms and policies to encourage foreign investment projects and other economic sectors to quickly put high technology and new technology into production, especially in high-value industries. From a practical perspective, the process of implementing industrialization and modernization in the past decade in the Southeast provinces has given us a number of lessons to be learned, and some lessons learned for promoting implementation in industrialization, modernization and soon bring Vietnam to complete the goal of industrialization and modernization, basically becoming an industrialized country in the direction of modernity. 


\section{References}

Anh, Q (2019). Vietnam on the path of innovation and creativity. National Center for Socio-Economic Information and Forecast - Ministry of Planning and Investment. http://ncif.gov.vn/Pages/NewsDetail.aspx?newid=21807

Chang, H.J., Andreoni, A. (2020). Industrial Policy in the 21st Century. Development and Change, 51(2), 324-351. https://doi.org/10.1111/dech.12570

Claude, A. (2013). Challenging science of the twenty-first century. Hanoi: Knowledge

Cuong, L. T. (2013). Agricultural modernization practice with Chinese characteristics and lessons learned for Vietnam. Electronic Communist Journal. https://www.tapchicongsan.org.vn/sinh-hoat-tu-tuong/-/2018/19693/thuc-tienhien-dai-hoa-nong-nghiep-dac-sac-trung-quoc-va-kinh-nghiem-rut-ra-cho-vietnam.aspx\#

Huong, N. T. T. (2015). Comparative study of development resources of Singapore and Korea in the period 1961 - 1979 (Doctoral thesis). Hanoi: University of Social Sciences and Humanities.

Huy, C.T. (2019). Factors affecting the attraction of foreign direct investment: A study on the Southeast economic region (Dissertation). Hanoi: Ho Chi Minh National Academy of Politics.

Kizuna (2020). Situation of human resources in Vietnam in 2020 and forecast in 2021. https://www.kizuna.vn/vi/tin-tuc/thuc-trang-nguon-nhan-luc-viet-nam-va-du-bao741.

Long, N.T. (2016). The process of social change in the first twenty years of renovation in Ho Chi Minh City, Dong Nai and Binh Duong (1986-2006) (PhD Thesis). University of Science and Technology. Ho Chi Minh City: University of Social Sciences and Humanities.

Ohno, K. (2006). The Economic Development of Japan: The Path Traveled by Japan as a Developing Country. Tokyo: https://www.grips.ac.jp/vietnam/VDFTokyo/Temp/Doc/2006/BookMar06_EDJ_E Fulltext.pdf

Phuong, D. T. H. (2019). Some basic characteristics of the process of industrialization and modernization in Vietnam from 1996 to present. Journal of Human Resources and Social Sciences, 7, 65 - 74.

Scott, A. J., \& Storper, M. (1992). Pathways to Industrialization and Regional Development. London: Routledge. DOI: https://doi.org/10.4324/9780203995549

Sen, V.V., \&T ien, T.N. (2013). Southern Vietnam in the period of international integration. Journal of Science and Technology Development, 16(X1), 16-33.

Son H. (2018). In 2017, what has science and technology contributed to the country? Dan Tri Electronic Newspaper. https://dantri.com.vn/khoa-hoc-cong-nghe/nam2017-khoa-hoc-va-cong-nghe-da-dong-gop-duoc-nhung-gi-cho-dat-nuoc20180109093100359.htm 
Szirmai, A., Naude, W., \& Alcorta, L. (2013). Pathways to Industrialization in the Twenty-First Century: New Challenges and Emerging Paradigms. United Kingdom: Oxford University Press. DOI:10.1093/acprof:oso/9780199667857.001,0001.

Thanh, L. T. (2019). Five years of looking back at the Belt and Road Initiative, challenges and prospects. Newspapers of the world and Vietnam. https://baoquocte.vn/5-nam-nhin-lai-sang-kien-vanh-dai-va-con-duong-thachthuc-va-trien-vong-92716.html

Tho, T. V. (2015). Time shock and Vietnam's economy. Hanoi:Knowledge Publishing House.

Toan, N. V. (2020). The path to the Japanese economic miracle. Vietnamnet electronic newspaper. https://vietnamnet.vn/vn/the-gioi/ho-so/con-duong-mang-lai-su-thanky-cua-kinh-te-nhat-ban-651660.html

UNDP. (2020). Human Development Report 2019 "Inequality in human development in the 21st century: Not only in terms of income, average and current".

Valve, H. (20190. Promoting the role of science and technology in rapid and sustainable development in Vietnam. Electronic Communist Journal. https://www.tapchicongsan.org.vn/kinh-te/-/2018/55000/phat-huy-vai-tro-cuakhoa-hoc-va-cong-nghe-trong-phat-trien-kinh-te-nhanh\%2C-ben-vung.aspx\#

Vogel, E. F, \& Kim, B.K. (2011). The Park Chung Hee Era. Cambridge, Massachusetts; London, England: Harvard University Press. http://www.jstor.org/stable/j.ctt24hjkq

Xuan, M. T. T. (2011). Some models of industrialization in the world and Vietnam. Ha Noi: Hanoi National University Publishing House. 